\title{
Clinical-dermatological, histological abnormalities and prevalence of Trypanosoma caninum and Leishmania infantum in dogs from Midwest region of Brazil
}

\author{
Anormalidades clínico-dermatológicas, histológicas e prevalência de \\ Trypanosoma caninum e Leishmania infantum em cães da região \\ Centro-Oeste do Brasil
}

Herica Makino ${ }^{1}$, Janaina Marcela Assunção Rosa Moreira ${ }^{1}$, Kalinne Stephanie Bezerra ${ }^{1}$, Amanda Atsumy Funakawa Otsubo ${ }^{2}$, Juliano Bortolini³, Valéria Régia Franco Sousa², Valeria Dutra², Edson Moleta Colodel², Luciano Nakazato², Arleana do Bom Parto Ferreira de Almeida ${ }^{2 *}$ (1)

${ }^{1}$ Programa de Pós-graduação em Ciências Veterinárias, Universidade Federal de Mato Grosso - UFMT, Cuiabá, MT, Brasil ${ }^{2}$ Faculdade de Medicina Veterinária, Universidade Federal de Mato Grosso - UFMT, Cuiabá, MT, Brasil

${ }^{3}$ Departamento de Estatística, Instituto de Ciências Exatas e da Terra, Universidade Federal de Mato Grosso - UFMT, Cuiabá, MT, Brasil

How to cite: Makino H, Moreira JMAR, Bezerra KS, Otsubo AAF; Bortolini J, Sousa VRF, Dutra V, Colodel EM, Nakazato L, Almeida ABPF. Clinical-dermatological, histological abnormalities and prevalence of Trypanosoma caninum and Leishmania infantum in dogs from Midwest region of Brazil. Braz J Vet Parasitol 2020; 29(1): e016319. https://doi.org/10.1590/S1984-29612019100

\begin{abstract}
Leishmania infantum is a trypanosomatid that causes parasitic dermatopathy in dogs. Trypanosoma caninum is another trypanosomatid, which infects the skin of dogs, although cutaneous abnormalities are absent. This study aimed to investigate the occurrence of $T$. caninum infection and its associated cutaneous and histological changes and compare it with the occurrence of $L$. infantum infection in dogs. The study included 150 dogs, of which $T$. caninum infection was identified in $3(2 \%)$ and L. infantum infection in $15(10 \%)$ of them, with no association ( $>>0.05)$ of these infections with the breed, gender, age, or cutaneous abnormalities. The cutaneous abnormalities were based on 1 (4.8\%) and 12 (57.1\%) dogs infected by $T$. caninum and $L$. infantum, respectively. The dermatohistopathological abnormalities in the dogs infected with $T$. caninum included mild perivascular lymphohistioplasmacytic infiltrates in the clinically asymptomatic ones, while in those with dermatological abnormalities, acanthosis, epidermal orthokeratotic hyperkeratosis, melanomacrophages, and co-infection with Microsporum sp. and Trichophyton sp. were observed. In L. infantum infected, the histopathological findings included chronic granulomatous inflammatory infiltrates and structures compatible with amastigotes. Despite the low frequency of $T$. caninum infection, our findings suggest that this trypanosomatid, unlike L. infantum, does not cause any macroscopic skin abnormalities.
\end{abstract}

Keywords: Trypanosomatids, dermatopathy, zoonosis, canine, skin.

\section{Resumo}

Leishmania infantum é um tripanosomatídeo que causa dermatopatia parasitária em cães. Trypanosoma caninum é outro tripanosomatídeo, que infecta a pele de cães, embora anormalidades cutâneas sejam ausentes. Este estudo teve como objetivo investigar a ocorrência da infecção por

Received September 10, 2019. Accepted October 30, 2019.

*Corresponding author: Arleana do Bom Parto Ferreira de Almeida. E-mail: arleferreira@gmail.com 
T. caninum e suas alterações cutâneas e histológicas associadas e compará-las com a ocorrência da infecção por $L$. infantum em cães. O estudo incluiu 150 cães, dos quais a infecção por $T$. caninum foi identificada em 3 (2\%) e a infecção por L. infantum em 15 (10\%) deles, sem associação $(p>0,05)$ dessas infecções com a raça, sexo, idade ou anormalidades cutâneas. As alterações cutâneas foram observadas em 1 (4,8\%) e 12 (57,1\%) cães infectados por T. caninum e L. infantum, respectivamente. As anormalidades dermato-histopatológicas nos cães infectados por T. caninum incluíram infiltrados linfo-histioplasmocitários perivasculares leves nos clinicamente assintomáticos, enquanto naqueles com anormalidades dermatológicas, foram observados acantose, hiperqueratose ortoqueratótica epidermal e melanomacrófagos e co-infecção por Microsporum sp. e Trichophyton sp. Nos cães infectados por $L$. infantum, os achados histopatológicos incluíram infiltrados inflamatórios granulomatosos crônicos e estruturas compatíveis com amastigotas. A despeito da baixa frequência da infecção por T. caninum, nossos achados sugerem que esse tripanosomatídeo, diferentemente de L. infantum, não causa anormalidades macroscópicas na pele.

Palavras-chave: Tripanosomatideos, dermatopatia, zoonose, canino, pele.

\section{Introduction}

Among parasitic dermatoses, those caused by the protozoa of the Trypanosomatidae family, especially of the Leishmania genus, are relevant to dogs residing in endemic areas of Brazil (Gasparetto et al., 2013). Although many Trypanosoma species affecting dogs have been described (Hoare, 1972), there is no description of the cutaneous changes caused by these protozoa. However, in 2009, a new Trypanosoma species, named Trypanosoma caninum, parasitizing the skin of a dog co-infected with Leishmania braziliensis was described (Madeira et al., 2009), suggesting that dermatological changes may be associated with this parasite.

Little is known about the development cycle, tropism, and pathogenicity of $T$. caninum (Madeira et al., 2009). T. caninum has been isolated only from the skin so far, a factor that is unusual of the Trypanosoma genus, and it shares the same reservoir with L. infantum, the infectious agent of visceral leishmaniasis (VL). It has been isolated from several regions of Brazil (Alves et al., 2012; Oliveira et al., 2015). These aspects raise some public health concerns, especially the risk of erroneous diagnoses of LVC in areas of sympatry of L. infantum and T. caninum (Almeida et al., 2011; Alves et al., 2012).

The aspects described above, and the limited information available related to the clinical aspects and the possible dermatological alterations associated with $T$. caninum infection in dogs motivated this study. We aimed to investigate the frequency of $T$. caninum infection in dogs selected at the University Veterinary Hospital of Cuiabá, Mato Grosso, Brazil, and examine possible dermatological and histological abnormalities in T. caninuminfected dogs and compare it to those seen in dogs infected with L. infantum.

\section{Materials and Methods}

\section{Dogs}

This study included 150 dogs, selected while attending clinic and dermatological at the Veterinary Hospital (HOVET) of the Federal University of Mato Grosso (UFMT) campus Cuiabá, Mato Grosso, from May 2015 to May 2016. As inclusion criteria, dogs with a history of dermatological alterations (symptomatic) and healthy dogs (asymptomatic) submitted to elective castration were selected. The cohort size was determined based on the number of dogs presented to the HOVET-UFMT annually, taking into account a $T$. caninum infection prevalence of 10.9\% (Pinto et al., 2014), and error margin $\leq 0.05$.

This study was approved by the Committee for Ethics in Animal Use (CEUA) of UFMT under $n^{\circ} 23108.102289 / 2015-92$ and executed according to the ethical principles. Informed consent was signed by the owner of each dog. 


\section{Clinical analysis: dermatology and complementary examinations}

Dermatological, epidemiological, and general clinical evaluations were performed on the dogs. The data related to the dermatological changes included macroscopic morphological characteristics (location, shape, and the intensity of changes) (Ginn et al., 1972; Scott et al., 2001). Based on the cutaneous changes found in the dogs, complementary tests including direct parasitological examination of samples acquired via skin scrapings or adhesive tape (Pereira et al., 2015); wood lamp examination; direct microscopic hair examination, after imbibition in 10\% potassium hydroxide, fungal culture, and cytological examination of fine-needle aspirates of skin samples (Bond, 2010) were performed for a definitive diagnosis of the dermatopathy.

\section{Detection of Trypanosoma caninum and Leishmania infantum infection}

Blood samples $(5 \mathrm{~mL})$ were collected by cephalic or jugular venipuncture using the aseptic technique into $10 \%$ sodium EDTA tubes for parasitological culture and molecular tests. In addition, five skin biopsies of dermatologically asymptomatic dogs and five skin biopsies from cutaneous lesions of dermatologically symptomatic dogs were collected. Three-millimetre tissue biopsies were obtained after trichotomy, antisepsis, and 2\% lidocaine local anaesthesia (Almeida et al., 2010) for parasitological culture, molecular testing, and histopathology.

\section{Parasitic isolation in culture medium}

Skin biopsies were immersed in sterile buffered saline containing penicillin, streptomycin, and fluorocytosine, and preserved at $4{ }^{\circ} \mathrm{C}$ for 24 hours. The samples were then seeded into screw-cap tubes containing blood-agar slants biphasic medium (Novy, MacNeal, Nicole - NNN - Sigma-Aldrich ${ }^{\circledR}$ ) overlaid with $2 \mathrm{~mL}$ of Schneider's Drosophila medium (Sigma-Aldrich ${ }^{\circledR}$ ) plus $10 \%$ fetal bovine serum (Sigma-Aldrich ${ }^{\circledR}$ ). Peripheral blood collected in tubes containing anticoagulants were seeded directly into the culture medium $(400 \mu \mathrm{L})$. The cultures were seeded in duplicates, placed in an incubator at $26-28^{\circ} \mathrm{C}$, and examined weekly for $40-50$ days by fresh tests to detect flagellate forms (Almeida et al., 2011).

\section{DNA extraction, Polymerase Chain Reaction (PCR) and sequencing}

DNA extraction from the skin and blood samples were performed using the phenol/chloroform method (Sambrook \& Russell, 2001). For the detection of $T$. caninum DNA, nested PCR was used with the outer primers TRY927F and TRY927R during the first round and the inner primers SSU561F and SSU561R, which amplify a conserved region of the $18 \mathrm{~S}$ rDNA (ribosomal DNA) gene of all trypanosomatids (Smith et al., 2008), during the second round. For the detection of an L. infantum infection, RV1 and RV2 primers were used to amplify a 145 bp region of kDNA (kinetoplast DNA) specific for this species (Lachaud et al., 2002). For both sets of primers, the L. infantum DNA (MHOM/BR/1974/PP75) was used as the positive control and a corresponding negative control (DNA free reaction) was included in every reaction.

The amplification products of the nested PCR and L. infantum specific PCR were fractionated by $2 \%$ agarose gel electrophoresis, stained with Red gel (Biotium ${ }^{\circledR}$ ) and viewed with ChemiDoc XRS using the Image Lab Software. A 100 bp molecular weight marker (Fermentas ${ }^{\circledR}$ ) was used. The products obtained by the $18 \mathrm{~S}$ rDNA nested PCR were purified using the GFX PCR DNA kit and sequenced using Sanger sequencing (Applies Biosystems ${ }^{\circledR}$ Genetic Analysis) for etiological characterization. The sequences obtained were deposited and compared to sequences of different species of trypanosomatids using GenBank. 


\section{Histopathological examination}

Skin sections were fixed in a $10 \%$ formalin solution, embedded in paraffin, cut into 5- $\mu \mathrm{m}$-thick sections, and stained with hematoxylin-eosin (HE) (Prophet et al., 1992).

\section{Statistical analysis}

The data were tabulated and analysed descriptively. The association of sex, breed and age with the presence of dermatological changes and T. caninum or L. infantum infection was examined using chi-square or Fisher Exact tests, using statistical software (Epi Info 3.3.2 program, CDC, Atlanta, GA). A P-value $<0.05$ was considered significant.

\section{Results}

The study included 150 dogs (males, $n=64,42.7 \%$; females, $n=86,57.3 \%$ ) of which 77 $(51.3 \%)$ were of mixed breed and $73(48.7 \%)$ were pure-breed dogs, with an overall median age of 4 years (range 2 months - 13 years). Dermatological abnormalities were noted in 117 dogs $(78 \%)$, including pruritus $(62.7 \%)$, alopecia or hypotrichosis $(60 \%)$, desquamation (60\%), hyperpigmentation (8\%), cutaneous ulceration $(4.7 \%)$, meliceric crusts $(4.7 \%)$, onychogriphosis (2.7\%) and lichenification (0.7\%).

In the parasitological culture, flagellar forms were isolated from two skin biopsies from two different dogs. By molecular analysis, trypanosomatid DNA was detected in 18 (12\%) dogs, independent of the samples and primers used (Table 1). T. caninum infection was detected in three dogs (2.0\%), all from skin samples, and identified using nested PCR. Sequencing of the amplification revealed $99.45 \%$ and $99.46 \%$ homology with $T$. caninum isolate 118 and $T$. caninum isolate MT604, respectively (GenBank accession number GU385825.1 and JF907512.1). L. infantum was detected in 15 (10\%) dogs in blood and/or skin samples, and revealed $99.62 \%, 99.23 \%$ and $99.81 \%$ homology with L. infantum isolate LL1678 LN, L. chagasi isolate LL2264 LN and L. infantum isolate LL1884 MO, respectively (GenBank accession number KU948456.1, KU948484.1 and KU948467.1\%, respectively). The positivity values for the agents, targets, and samples investigated are included in Table 1.

Table 1. Positivity to Trypanosoma caninum and Leishmania infantum in blood and skin samples in molecular analysis using the $18 \mathrm{~S}$ rDNA and Leishmania kDNA targets.

\begin{tabular}{|c|c|c|c|c|c|}
\hline \multirow{2}{*}{ Agent } & \multirow{2}{*}{$\begin{array}{c}\text { Dogs } \\
\mathrm{n}=150 \\
\text { Positive }\end{array}$} & \multicolumn{2}{|c|}{ 18S rDNA } & \multicolumn{2}{|c|}{ kDNA } \\
\hline & & Blood & Skin & Blood & Skin \\
\hline \multicolumn{6}{|l|}{ Asymptomatic dogs } \\
\hline Trypanosoma caninum & 2 & 0 & 2 & 0 & 0 \\
\hline Leishmania infantum & 3 & 0 & 1 & 2 & 0 \\
\hline \multicolumn{6}{|l|}{ Symptomatic dogs } \\
\hline Trypanosoma caninum & 1 & 0 & 1 & 0 & 0 \\
\hline Leishmania infantum & 12 & 2 & 5 & 4 & 7 \\
\hline
\end{tabular}

T. caninum and $L$. infantum infections were not significantly associated ( $p>0.05$ ) with the breed, sex, age, or the presence of dermatopathies. T. caninum infection was detected in two (1.3\%) asymptomatic dogs and one (0.7\%) dog which presented skin pruritus with alopecia and desquamation. L. infantum infection was found in three (9.1\%) asymptomatic dogs and twelve (10.2\%) dogs which showed the following clinical findings: alopecia (75\%), desquamation (75\%), pruritus (67\%), cutaneous ulceration (33\%), and onychogriphosis (25\%).

Of the 117 dermatologically symptomatic dogs studied, a dermatopathic presumptive diagnosis was made based on laboratory and histopathological examination in $82 \%$ of the cases, while results were inconclusive in $18 \%$. The presumptive diagnoses included allergic 
(16\%), parasitic (15.3\%), fungal (14.7\%), bacterial (2.0\%), endocrine (1.3\%), immune-mediated $(0.7 \%)$ and hereditary $(0.7 \%)$ dermatopathies, as well as keratinization defects $(3.3 \%)$.

One hundred of the fungal cultures (66.7\%) were positive for Microsporum spp. or Trichophyton spp., of which, twelve dogs (12\%) were positive for L. infantum and three (3.0\%) were positive for $T$. caninum. Demodex or Sarcoptes mites were detected by skin scrapings or adhesive tape in eleven dogs (7.3\%). One (0.7\%) of the dogs detected with demodicosis was positive for $L$. infantum.

The skin histopathology results of the infected dogs are presented in Table 2. In three L. infantum infected dogs (20\%), no histopathological abnormalities were observed. In one dog, the changes were suggestive of endocrinopathy, characterized by acanthosis, epidermal and follicular infundibulum orthokeratotic hyperkeratosis, and hair follicle and sebaceous gland atrophy.

Table 2. Skin histopathological findings of dogs infected with Trypanosoma caninum or Leishmania infantum.

\begin{tabular}{lll}
\hline \multicolumn{1}{c}{ Histopathological changes } & \multicolumn{1}{c}{ T. caninum infection } \\
$(\mathbf{n = 3})$ & $\begin{array}{c}\text { L. infantum } \\
\text { infection }(\mathbf{n}=\mathbf{1 5})\end{array}$ \\
\hline Epidermis & $33 \%(1)$ & $7 \%(1)$ \\
\hline Acanthosis & $33 \%(1)$ & $7 \%(1)$ \\
\hline Orthokeratotic hyperkeratosis & & \\
\hline Dermis & $67 \%(2)$ & $47 \%(7)$ \\
\hline Lymphohistioplasmacytic perivascular infiltrate & $0 \%(0)$ & $13 \%(2)$ \\
\hline $\begin{array}{l}\text { Lymphohistioplasmacytic perivascular/perionxys } \\
\text { infiltrate }\end{array}$ & $0 \%(0)$ & $7 \%(1)$ \\
\hline Perivascular/perionxys pyogranulomatous infiltrate & $33 \%(1)$ & $7 \%(0)$ \\
\hline Melanomacrophages & $0 \%(0)$ & $7 \%(1)$ \\
\hline Atrophy of the hair follicles and sebaceous glands & $0 \%(0)$ & \\
\hline L. infantum amastigotes & &
\end{tabular}

\section{Discussion}

The present study conducted in an endemic area of $T$. caninum and $L$. infantum showed infection occurrence rates of $2 \%$ and $8 \%$ for these parasites, respectively, in agreement with previous findings (Gasparetto et al., 2013; Pinto et al., 2014). Infections by different protozoa of the Trypanosomatidae family in canines have been described previously (Nwoha, 2013). In this scenario, L. infantum infection has important public health implications (Madeira et al., 2006) due to the relevance of dogs as a reservoir of zoonotic visceral leishmaniasis. The recent isolation of $T$. caninum from dogs' skin samples in endemic areas for visceral leishmaniasis has called attention to this protozoan (Barros et al., 2012; Oliveira et al., 2015).

In addition, $T$. caninum infection was identified only in skin samples, even when parasitological culture and molecular analysis of blood samples were utilized (Pinto et al., 2014; Madeira et al., 2014). Skin was also the biological sample with the highest detection rate of $L$. infantum in symptomatic and asymptomatic dogs, independent of the target gene sequences used. Despite the low number of $T$. caninum positive dogs, the present results reinforce the finding that $T$. caninum infection is restricted to the skin (Madeira et al., 2014). Conventional PCR and parasitological culture, presently utilized for identifying $T$. caninum infection, might not be sensitive enough to detect very low parasite burdens, possibly limiting the detection of this parasite, especially since little is known of its pathogenesis and biological cycle (Almeida et al., 2011; Madeira et al., 2014). However, the importance of dogs in canine visceral leishmaniasis (CVL) reinforces the need to promote the distinction of these agents (Barros et al., 2012). 
Although the 18S rDNA gene detects Leishmania DNA, the use of the primers with a conserved region of $L$. infantum $\mathrm{kDNA}$ employed in this research obtained a higher positivity for this region, which makes it a good diagnostic method for visceral leishmaniasis, especially in endemic and sympatric areas. These results are consistent with those obtained by Pinto et al. (2014). However, regarding L. infantum, it is important to submit several biological samples for specific PCR and parasitological cultures, in order to have higher chances of detecting this agent (Almeida et al., 2011, 2013). The use of specific T. caninum primers might be more effective for its detection, as described for LVC. In this study, there was no association of $T$. caninum or L. infantum infection with age, breed, and sex, which is in agreement with previous findings in cases of visceral leishmaniasis (Almeida et al., 2009; Oliveira et al., 2010), while $T$. caninum has been detected in asymptomatic dogs aged 3 to 5 years (Oliveira et al., 2015). Nevertheless, the present $T$. caninum infection rate should be accepted cautiously, due to the low number of infected dogs.

Dermatological changes are frequently reported in L. infantum infections in canines (Queiroz et al., 2011; Silva et al., 2017). In this study, the main dermatological signs in dogs that were positive for this agent were alopecia, desquamation, pruritus, skin ulcers, and onychogriphosis. These findings are consistent with those of other authors (Almeida et al., 2009; Solano-Gallego et al., 2009). The occurrence of cutaneous coinfections, mainly fungal are the result of opportunist agents (Gasparetto et al., 2013), but concomitant dermatological diseases can be associated with LVC. Nevertheless, in cases of LVC, many dogs may be asymptomatic (Almeida et al., 2009; Barros et al., 2012), as was observed herein.

The isolation and detection of $T$. caninum DNA exclusively in intact skin has been considered a peculiar aspect of this agent (Madeira et al., 2014). According to Alves et al. (2012), T. caninum can provoke an insufficient mild humoral response to cause clinical lesions, however, no significant histopathological changes related to this infection have been described yet. In this study, only one dog positive for T. caninum infection presented dermatological abnormalities, characterized by multifocal alopecia, meliceric crusts, and generalized desquamation. Nevertheless, the present results should be interpreted cautiously, since this dog was also positive for dermatophytosis based on fungal culture (Mattei et al., 2014), which affects keratinized tissues (Nweze, 2011), and leads to similar morphological changes as described in the presented dog (Bond, 2010).

The main histopathological change seen in asymptomatic animals with $T$. caninum infection was a mild lymphoplasmacytic inflammatory infiltrate (Figure 1A). However, the significance of this mild infiltrate might be questionable, because lymphocytes and plasma cells in small numbers are also present in the dermis of healthy dogs (Hargis \& Ginn, 2007). The finding of acanthosis, epidermal orthokeratotic hyperkeratosis, and presence of melanomacrophages in the dermis of the dog with dermatological changes could not be associated with $T$. caninum infection due to the fungal co-infection with Microsporum sp. and Trichophyton sp., which produce similar changes (Bond, 2010). 


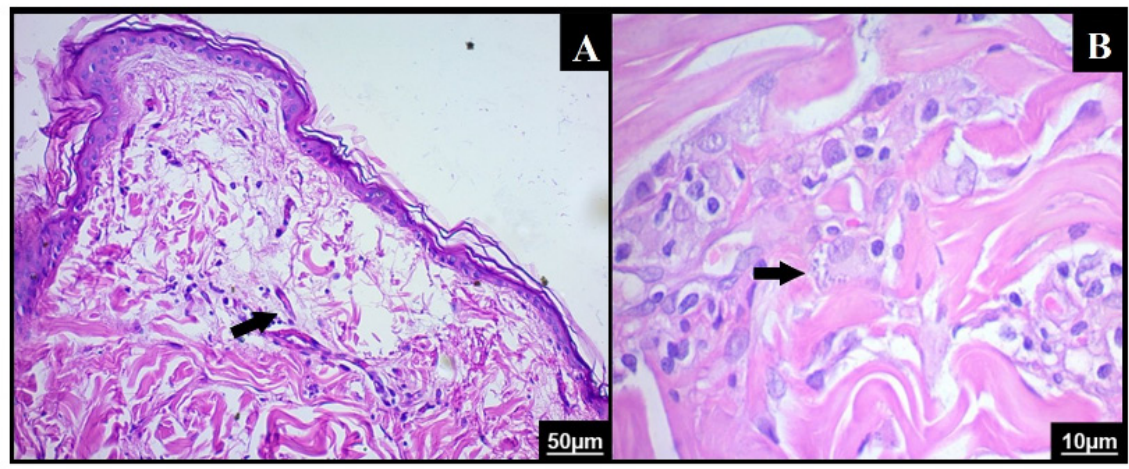

Figure 1. (A) The skin of a dog positive for Trypanosoma caninum presenting with lymphohistioplasmacytic perivascular inflammatory infiltrate (arrow). Magnification: 20X (HE); (B) The skin of a dog positive for Leishmania infantum with perivascular and perifollicular infiltrate, lymphohistioplasmocitary, and amastigotes of Leishmania sp (arrow). Magnification: 60X (HE).

Histopathological changes consistent with dermatitis have been described in CVL (Queiroz et al., 2011). Perivascular and perifollicular changes are the most common, even in absence of the Leishmania sp. amastigotes (Figure 1B). However, similar to the present study, chronic dermatitis, manifested by mononuclear cell, including plasma cells, macrophages and lymphocytes, infiltration was also described in dogs with and without $C V L$, and in those with the presence or absence of amastigotes (Figueiredo et al., 2010). The presence of mild lymphohistioplasmacytic inflammatory infiltrate that is commonly found in healthy tissue was also observed in dogs with leishmaniasis without clinical symptoms as well as in dogs infected with $T$. caninum. However, in animals with visceral leishmaniasis, an asymptomatic infection may persist for years before the development of clinical symptoms (Baneth et al., 2008); whereas, in a T. caninum infection, it is not yet known what the incubation period is or if this parasite is capable of producing clinical signs in infected dogs throughout the course of the disease. The presence of more than one inflammatory pattern, mixed inflammatory patterns, or an overlapping of histological patterns may be observed in L. infantum infections in dogs (Torres et al., 2008). CVL leads to diverse clinical and histological manifestations and the latter mostly demonstrates mild to marked inflammatory infiltrates, depending on host resistance variations (Calabrese et al., 2010). These findings may change due to cutaneous coinfections and concomitant diseases (Gross et al., 2005), such as dermatophytosis fungal, observed in $64.7 \%$ of $L$. infantum positive dogs herein, or hypothyroidism, where the characteristics were more suggestive of atrophic dermatoses than that of parasitic dermatoses.

\section{Conclusion}

The presence of nonspecific changes found in the histology of dogs with and without dermatopathies leads us to infer that $T$. caninum may not induce a cutaneous inflammatory reaction. However, more studies are necessary to better characterize the clinical and histological changes induced by this agent.

\section{Acknowledgements}

The Coordenação de Aperfeiçoamento de Pessoal de Nível Superior (CAPES) Brasil for financial fellowship. 


\section{References}

Almeida ABPF, Faria RP, Pimentel MFA, Dahroug MAA, Turbino NCMR, Sousa VRF. Inquérito soroepidemiológico de leishmaniose canina em áreas endêmicas de Cuiabá, Estado de Mato Grosso. Rev Soc Bras Med Trop 2009; 42(2): 156-159. http://dx.doi.org/10.1590/S003786822009000200012 . PMid:19448933.

Almeida ABPF, Mendonça AJ, Sousa VRF. Prevalência e epidemiologia da leishmaniose visceral em cães e humanos, na cidade de Cuiabá, Mato Grosso, Brasil. Cienc Rural 2010; 40(7): 1610-1615. http://dx.doi.org/10.1590/S0103-84782010005000102.

Almeida ABPF, Sousa VRF, Boa-Sorte EC, Figueiredo FB, Paula DA, Pimentel MFA, et al. Use of parasitological culture to detect Leishmania (Leishmania) chagasi in naturally infected dogs. Vector Borne Zoonotic Dis 2011; 11(12): 1555-1560. http://dx.doi.org/10.1089/vbz.2011.0723. PMid:21919725.

Almeida ABPF, Sousa VRF, Gasparetto ND, Silva GFR, Figueiredo FB, Dutra V, et al. Canine visceral leishmaniasis: diagnostic approaches based on polymerase chain reaction employing different biological samples. Diagn Microbiol Infect Dis 2013; 76(3): 321-324.

http://dx.doi.org/10.1016/j.diagmicrobio.2013.03.017. PMid:23619344.

Alves AS, Mouta-Confort E, Figueiredo FB, Oliveira RV, Schubach AO, Madeira MF. Evaluation of serological cross-reactivity between canine visceral leishmaniasis and natural infection by Trypanosoma caninum. Res Vet Sci 2012; 93(3): 1329-1333. http://dx.doi.org/10.1016/j.rvsc.2012.07.006. PMid:22840335.

Baneth G, Koutinas AF, Solano-Gallego L, Bourdeau P, Ferrer L. Canine leishmaniosis - new concepts and insights on an expanding zoonosis: part one. Trends Parasitol 2008; 24(7): 324-330. http://dx.doi.org/10.1016/j.pt.2008.04.001. PMid:18514028.

Barros JHS, Almeida ABPF, Figueiredo FB, Sousa VR, Fagundes A, Pinto AG, et al. Occurrence of Trypanosoma caninum in areas overlapping with leishmaniasis in Brazil: what is the real impact of canine leishmaniasis control? Trans R Soc Trop Med Hyg 2012; 106(7): 419-423. http://dx.doi.org/10.1016/j.trstmh.2012.03.014. PMid:22579558.

Bond R. Superficial veterinary mycoses. Clin Dermatol 2010; 28(2): 226-236. http://dx.doi.org/10.1016/j.clindermatol.2009.12.012. PMid:20347667.

Calabrese KS, Cortada VM, Dorval ME, Souza Lima MA, Oshiro ET, Souza CS, et al. Leishmania (Leishmania) infantum/chagasi: histopathological aspects of the skin in naturally infected dogs in two endemic areas. Exp Parasitol 2010; 124(3): 253-257. http://dx.doi.org/10.1016/j.exppara.2009.10.005. PMid:19854175.

Figueiredo MM, Moura EP, Costa MM, Ribeiro VM, Michalick MS, Tafuri WL, et al. Histopathological and parasitological investigations of ear healthy skin of dogs naturally and experimentally infected with Leishmania (Leishmania) chagasi. Histol Histopathol 2010; 25(7): 877-887. http://dx.doi.org/10.14670/HH-25.877. PMid:20503176.

Gasparetto ND, Trevisan YPA, Almeida NB, Neves RCSM, Almeida ABPF, Dutra V, et al. Prevalência das doenças de pele não neoplásicas em cães no município de Cuiabá, Mato Grosso. Pesq Vet Bras 2013; 33(3): 359-362. http://dx.doi.org/10.1590/S0100-736X2013000300014.

Ginn PE, Mansel JEKL, Rakich PM. Skin and appendages. In: Hoare CA, editor. The trypanosomes of mammals: a zoological monograph. Oxford: Blackwell Scientific Publications; 1972. p. 671-672.

Gross TL, Ihrke PJ, Walder EJ, Affolter VK. Skin diseases of the dog and cat: clinical and histopathologic diagnosis. 2nd ed. Ames: Blackwell Science; 2005. http://dx.doi.org/10.1002/9780470752487.

Hargis AM, Ginn PE. The integument. In: McGavin MD, Zachary JF, editors. Pathologic basis of veterinary disease. 4th ed. Mosby: St Louis; 2007. p. 1107-1261.

Hoare CA. Herpetosoma from man and other mammals. In: Hoare CA, editor. The trypanosomes of mammals: a zoological monograph. Oxford: Blackwell Scientific; 1972. p. 288-314.

Lachaud L, Marchergui-Hammami S, Chabbert E, Dereure J, Dedet JP, Bastien P. Comparison of six PCR methods using peripheral blood for detection on canine visceral leishmaniasis. J Clin Microbiol 2002; 40(1): 210-215. http://dx.doi.org/10.1128/JCM.40.1.210-215.2002. PMid:11773118.

Madeira M, Schubach ADO, Schubach TM, Pereira AS, Figueiredo FB, Baptista C, et al. Post mortem parasitological evaluation of dogs seroreactive for Leishmania from Rio de Janeiro, Brazil. Vet 
Parasito/ 2006; 138(3-4): 366-370. http://dx.doi.org/10.1016/j.vetpar.2006.01.059. PMid:16520002.

Madeira MF, Almeida ABPF, Barros JH, Oliveira TS, Sousa VR, Alves AS, et al. Trypanosoma caninum, a new parasite described in dogs in Brazil: aspects of natural infection. J Parasitol 2014; 100(2): 231-234. http://dx.doi.org/10.1645/13-297.1. PMid:24328788.

Madeira MF, Sousa MA, Barros JH, Figueiredo FB, Fagundes A, Schubach A, et al. Trypanosoma caninum n. sp. (Protozoa: Kinetoplastida) isolated from intact skin of a domestic dog (Canis familiaris) captured in Rio de Janeiro, Brazil. Parasitology 2009; 136(4): 411-423. http://dx.doi.org/10.1017/S003118200900554X. PMid:19216827.

Mattei AS, Madrid IM, Santin R, Schuch LPD, Meireles MCA. Presença de fungos com potencial patogênico em instrumentos de tosa. Arch Vet Sci 2014; 19(2): 40-45. http://dx.doi.org/10.5380/avs.v19i2.32998.

Nweze El. Dermatophytoses in domesticated animals. Rev Inst Med Trop São Paulo 2011; 53(2): $94-99$. http://dx.doi.org/10.1590/S0036-46652011000200007. PMid:21537757.

Nwoha RIO. A review on trypanosomiasis in dogs and cats. Afr J Biotechnol 2013; 12(46): 6432-6442. http://dx.doi.org/10.5897/AJB2013.12093.

Oliveira LCP, Araújo RR, Alves CR, Mouta-Confort E, López JÁ, Mendonça-Lima FW. Seroprevalence and risk factors for canine visceral leishmaniasis in the endemic area of Dias D'Ávila, State of Bahia, Brazil. Rev Soc Bras Med Trop 2010; 43(4): 400-404. http://dx.doi.org/10.1590/S003786822010000400013. PMid:20802939.

Oliveira TS, Barros JH, Perez TD, Figueiredo FB, Mendes AAV Jr, Madeira MF. Report of new cases of Trypanosoma caninum in Brazil. Rev Soc Bras Med Trop 2015; 48(3): 347-349. http://dx.doi.org/10.1590/0037-8682-0307-2014. PMid:26108017.

Pereira DT, Castro LJM, Centenaro VB, Amaral AS, Krause A, Schmidt C. Skin impression with acetate tape in Demodex canis and Sarcoptes scabiei var. vulpes diagnosis. Arq Bras Med Vet Zootec 2015; 67(1): 49-54. http://dx.doi.org/10.1590/1678-6869.

Pinto AGS, Toma HK, Figueiredo FB, Madeira MF. Evaluation of 18S rDNA PCR assay using skin fragments as a diagnostic test for Trypanosoma caninum. Vet Parasito/ 2014; 205(1-2): 343-346. http://dx.doi.org/10.1016/j.vetpar.2014.07.028. PMid:25131189.

Prophet EB, Mills B, Arrington JB, Sobin LH. Laboratory methods in histotechnology. Washington: DC American Registry of Pathology; 1992.

Queiroz NMGP, Silveira RCV, de Noronha ACF Jr, Oliveira TM, Machado RZ, Starke-Buzetti WA. Detection of Leishmania (L.) chagasi in canine skin. Vet Parasitol 2011; 178(1-2): 1-8. http://dx.doi.org/10.1016/j.vetpar.2010.12.033. PMid:21295916.

Sambrook J, Russell DW. Molecular cloning a laboratory manual. 3rd ed. New York: Cold Spring Harbor Laboratory; 2001.

Scott DW, Miller DH, Griffin CE. Muller and Kirk's: small animal dermatology. 6th ed. Philadelphia: Saunders; 2001.1528 p.

Silva KR, Mendonça VRR, Silva KM, Nascimento LFM, Mendes-Sousa AF, Pinho FA, et al. Scoring clinical signs can help diagnose canine visceral leishmaniasis in a highly endemic area in Brazil. Mem Inst Oswaldo Cruz 2017; 112(1): 53-63. http://dx.doi.org/10.1590/0074-02760160305. PMid:28076469.

Smith A, Clark P, Averis S, Lymbery AJ, Wayne AF, Morris KD, et al. Trypanosomes in a declining species of threatened Australian marsupial, the brush-tailed Bettongia penicillata (Marsupialia: potoroidae). Parasitology 2008; 135(11): 1329-1335. http://dx.doi.org/10.1017/S0031182008004824. PMid:18752704.

Solano-Gallego L, Koutinas A, Miró G, Cardoso L, Pennisi MG, Ferrer L, et al. Directions for the diagnosis, clinical staging, treatment and prevention of canine leishmaniosis. Vet Parasitol 2009; 165(1-2): 1-18. http://dx.doi.org/10.1016/j.vetpar.2009.05.022. PMid:19559536.

Torres R No, Rodrigues MMP, Amorim RL, Conceição LG, Luvizotto MCR, Franco SRVS. Padrões histopatológicos das lesões descamativas e ulcerativas da pele em cães com leishmaniose. Semina: Ciênc Agrár 2008; 29(3): 667-676. http://dx.doi.org/10.5433/1679-0359.2008v29n3p667. 